\title{
The Crinoid Fauna (Echinodermata: Crinoidea) of Palau ${ }^{1}$
}

\author{
Charles G. Messing ${ }^{2}$
}

\begin{abstract}
Taxonomic revisions and a recent survey using scuba place the number of shallow-water $(<50 \mathrm{~m})$ crinoid species known from Palau at 22. Five are new records: Clarkcomanthus littoralis, Comanthus suavia, Alloeocomatella pectinifera, Oxycomanthus comanthipinna, and O. exilis. A submersible survey (to $310 \mathrm{~m}$ ) recovered five additional new records, four of which are the first representatives of their families from Palauan waters: Eudiocrinus venustulus (Eudiocrinidae), Glyptometra sp. (Charitometridae), Cosmiometra belsuchel Messing, n. sp. (Thalassometridae), and Porphyrocrinus verrucosus (Phrynocrinidae), the first stalked crinoid recorded from Palau. Two of the three specimens of the latter have regenerating crowns, suggesting that this species may be subject to substantial predation or an unstable environment.
\end{abstract}

IN The LATE 1970s, Meyer and Macurda (1980) carried out the first comprehensive investigation of any tropical Indo-West-Pacific crinoid fauna using modern methods (scuba) rather than dredging and trawling. In the course of 96 dives at 22 sites in Palauan waters, they recorded 21 species of unstalked crinoids (comatulids, or feather stars), plus one additional species collected from a deepwater Nautilus trap. At the time, their data represented the richest shallow-water crinoid fauna of any locality outside Indonesia and the Great Barrier Reef. Since then, additional crinoid surveys have been carried out in the region from Japan to New Caledonia and from the Sulu Sea to Kwajalein Atoll (Zmarzly 1984, 1985, Meyer 1986, Bradbury et al. 1987, Chen et al. 1988, Messing 1994, 1998a, Kogo 1998), although few have been as extensive.

Briefly, the East Indian Archipelago (the islands of Indonesia, Malaysia, Papua New Guinea, and the Philippines) harbors the greatest richness in the Indo-West-Pacific re-

\footnotetext{
${ }^{1}$ Manuscript accepted 28 April 2006.

2 Oceanographic Center, Nova Southeastern University, 8000 North Ocean Drive, Dania Beach, Florida 33004 (phone: 954-262-3658; fax: 954-262-4098; e-mail: messingc@nsu.nova.edu).
}

Pacific Science (2007), vol. 61, no. 1:91-111

(C) 2007 by University of Hawai'i Press

All rights reserved gion, with $\sim 110$ crinoid species in $<50 \mathrm{~m}$ depth and $\sim 125$ (including 18 stalked taxa) in 100-1,000 m (Gislén 1938, A. M. Clark and Rowe 1971, Améziane 1991, 1997, Messing et al. 2000, Roux et al. 2002). Numbers are approximate because numerous taxonomic problems exist. Faunal richness generally declines outward in all directions, although more shallow-water species (57) have been recorded from Lizard Island, Great Barrier Reef, than at any other individual locality, at least in part due to an extensive two-decadelong collecting effort (Messing 1998a).

This paper was prompted by a recent survey of the Palauan shallow-water crinoid fauna, under the auspices of the Coral Reef Research Foundation (CRRF), Koror, Palau, using taxonomic revisions published since the original survey (Hoggett and Rowe 1986, Rowe et al. 1986, Messing 1995, 1998b, Rowe and Gates 1995) and collections made by CRRF in deeper water using the Deepworker 2000 manned submersible that include the first stalked crinoid recorded from Palauan waters. Terminology follows Messing (1997, 2001), Messing et al. (2000), and, for the stalked crinoid, Roux et al. (2002). The results are discussed in the context of the most recent available information on the distribution of Indo-West-Pacific crinoids.

\section{MATERIALS AND METHODS}

Seventeen dives were made at 15 sites between 24 November and 4 December 2002 


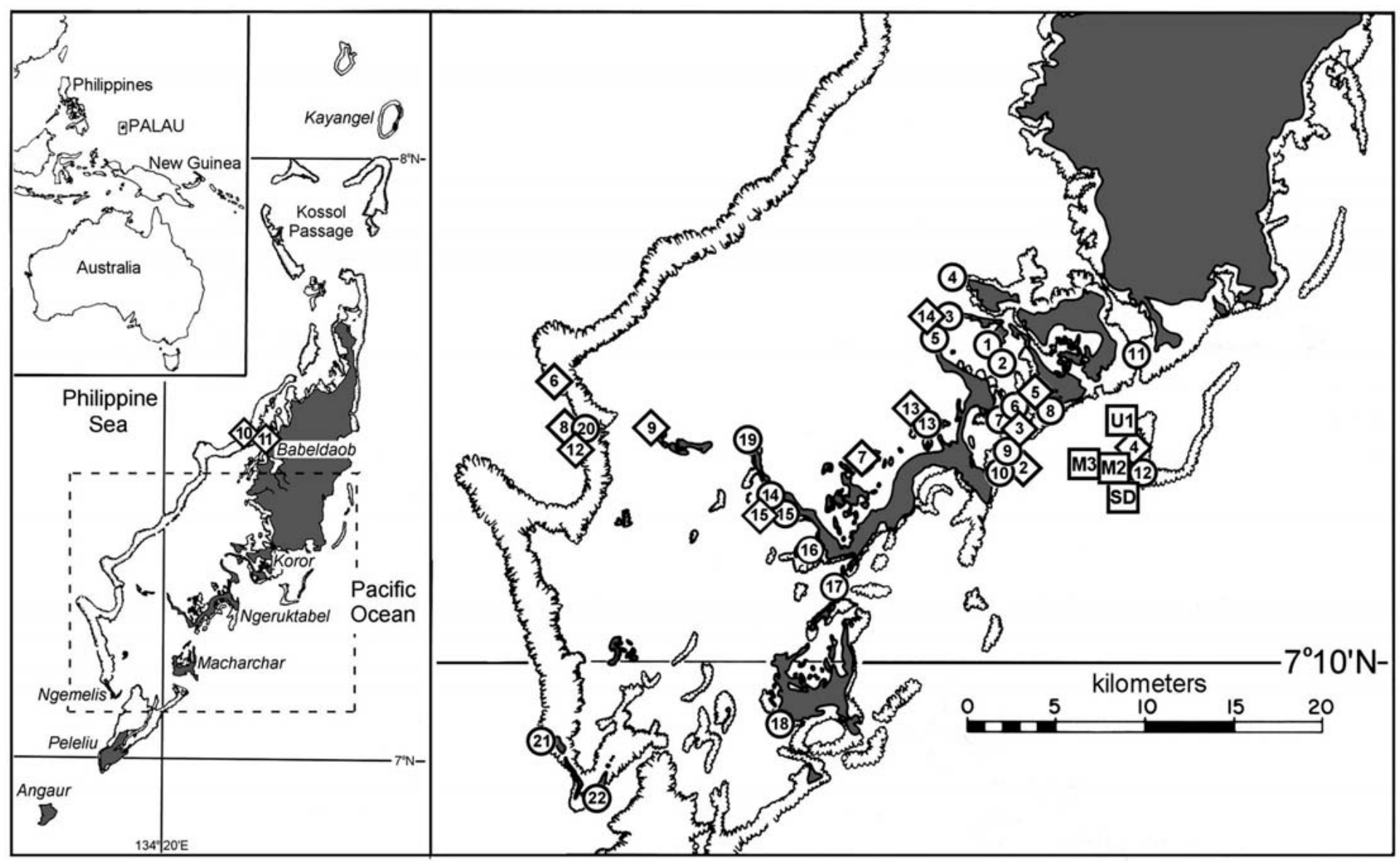

Figure 1. Crinoid survey sites. Dashed square in map on left indicates area of enlarged map on right. $\bigcirc$, Meyer and Macurda (1980) survey sites; $\diamond$, 2002 survey sites (note sites 10 and 11 in map on left); $\square, 2001$ submersible sites. Site symbols may be offset to avoid overlap. After maps by Meyer and Macurda (1980); used with permission. 
to a maximum depth of $31 \mathrm{~m}$ (Figure 1), as follows. Three were at night. Crinoids were found at all but site 7 . Depths (rounded to the nearest meter) are maximums for each site.

Site 1: Ngerikuul Pass, between Ngeteklou I. and Ngermeuangel I.; $07^{\circ} 19.13^{\prime} \mathrm{N}, 134^{\circ}$ $29.87^{\prime} \mathrm{E} ; 20 \mathrm{~m}$; rubble slope with scattered large coral heads, boulders, abundant Carijoa sp. and hydroids; slope gentle and sandy with scattered rubble below $17 \mathrm{~m}$.

Site 2: Lighthouse Reef, SW of lighthouse at entrance to Malakal Harbor, E of Ngeruktabel I.; $07^{\circ} 16.521^{\prime} \mathrm{N}, 134^{\circ} 27.587^{\prime} \mathrm{E} ; 20 \mathrm{~m}$; slope with widely spaced buttresses and broad grooves filled chiefly with Acropora sp. rubble; scattered domes of finely branched Millepora sp.

Site 3: Lighthouse Channel; $07^{\circ} 17.594^{\prime}$ $\mathrm{N}, 134^{\circ} 27.404^{\prime} \mathrm{E} ; 17 \mathrm{~m}$; reef slope with scattered large octocoral fans and Tubastraea micrantha.

Site 4: Mutremdiu, $W$ side of Uchelbeluu Reef; $07^{\circ} 16.41^{\prime} \mathrm{N}, 134^{\circ} 31.43^{\prime} \mathrm{E} ; 27 \mathrm{~m}$.

Site 5: (night) Ngederrak Reef, at east entrance to Malakal Harbor, sea-grass bed; $07^{\circ} 17.90^{\prime} \mathrm{N}, 134^{\circ} 28.34^{\prime} \mathrm{E} ; 1 \mathrm{~m}$; abundant macroalgae (e.g., Halimeda sp.), scattered Enbalus sp., branching Millepora sp., and small Porites lutea.

Site 6: Siaes Reef, western barrier reef; $07^{\circ}$ $18.76^{\prime} \mathrm{N}, 134^{\circ} 13.50^{\prime} \mathrm{E}$; $31 \mathrm{~m}$; vertical dropoff with large cave below $26 \mathrm{~m}$.

Site 7: Rock islands $W$ of Ngeruktabel I.; $07^{\circ} 16.11^{\prime} \mathrm{N}, 134^{\circ} 22.86^{\prime} \mathrm{E}$; $13 \mathrm{~m}$; slope and shallow wall flanking archway under small island (Soft Coral Arch). [No crinoids.]

Site 8: Ulong Rock, western barrier reef, just $\mathrm{N}$ of Ngerumekaul (Ulong Channel); $07^{\circ} 17.425^{\prime} \mathrm{N}, 134^{\circ} 14.463^{\prime} \mathrm{E}$; $31 \mathrm{~m}$; vertical drop-off below eroded, rubbly spur and groove topography.

Site 9: $W$ of Ulong I.; $07^{\circ} 17.162^{\prime} \mathrm{N}, 134^{\circ}$ $16.867^{\prime}$ E; $2 \mathrm{~m}$; patch reefs, isolated Porites lutea heads and in situ dead Acropora sp. on sand.

Site 10: $\mathrm{N}$ side of Toachel Mlengui (West Channel), $\mathrm{W}$ of Babeldaob I.; $07^{\circ} 32.538^{\prime} \mathrm{N}$, $134^{\circ} 28.219^{\prime} \mathrm{E} ; 27 \mathrm{~m}$; outer reef slope and vertical escarpment.

Site 11: N side Ngermetengel Channel, channel in fringing reef on $W$ side of Babeldaob I.; $07^{\circ} 31.730^{\prime} \mathrm{N}, 134^{\circ} 29.719^{\prime} \mathrm{E} ; 17 \mathrm{~m}$; steep reef slope.

Site 12: (2 dives) Ngerumekaul (Ulong Channel) $W$ entrance; $07^{\circ} 17.00^{\prime} \mathrm{N}, 134^{\circ}$ $14.730^{\prime} \mathrm{E} ; 17,20 \mathrm{~m}$; broad spur and groove slopes and rubbly channel.

Site 13 (snorkel): Iro Lake Tunnel, $W$ of Ngeruktabel I.; $07^{\circ} 17.390^{\prime} \mathrm{N}, 134^{\circ} 25.020^{\prime}$ $\mathrm{E} ; 1 \mathrm{~m}$; tunnel to Iro Lake with numerous Dendronephthya sp. (photographed in Hamner [1982] as Soft Coral Lake).

Site 14: (2 dives, night) Pinchers Lagoon, bay at $W$ end of Ngerchaol I.; $07^{\circ} 20.483^{\prime}$ $\mathrm{N}, 134^{\circ} 25.777^{\prime} \mathrm{E} ; 19 \mathrm{~m}$; reef slope with huge Porites sp. and large domelike branching Millepora sp.

Site 15: Just $S$ of $W$ end of Ngeruktabel I.; $07^{\circ} 15.346^{\prime} \mathrm{N}, 134^{\circ} 20.379^{\prime} \mathrm{E} ; 18 \mathrm{~m}$; abundant large Porites sp. and staghorn Acropora sp. rubble in 2-6 m; mud bottom below $11 \mathrm{~m}$.

Crinoids were collected during four Deepworker 2000 submersible dives; data are as follows. Depths and substrates are given for individual species, where known.

Uchelbeluu 1, W side of Uchelbeluu Reef, $07^{\circ} 17.395^{\prime} \mathrm{N}, 134^{\circ} 31.229^{\prime} \mathrm{E}, 25$ February 2001.

Short Drop-off, SW corner of Uchelbeluu Reef, $07^{\circ} 15.614^{\prime} \mathrm{N}, 134^{\circ} 31.13^{\prime} \mathrm{E}, 1$ March 2001.

Mutremdiu 2, W side of Uchelbeluu Reef, $07^{\circ} 16.41-43^{\prime} \mathrm{N}, 134^{\circ} 31.43^{\prime} \mathrm{E}, 14$ March 2001.

Mutremdiu 3, W side of Uchelbeluu Reef, $07^{\circ} 16.269^{\prime} \mathrm{N}, 134^{\circ} 31.370^{\prime} \mathrm{E}, 24$ March 2001.

Voucher specimens are held at the CRRF at Koror, Palau (CRECH catalog numbers). Type specimens have been deposited in the collection of the Department of Invertebrate Zoology, National Museum of Natural History, Smithsonian Institution, Washington, D.C. (UsNm catalog numbers). Specimens of some common shallow-water taxa were identified in situ and not collected or, if collected, were subsequently returned to the sea, used in feeding experiments, or deposited at the Palau International Coral Reef Conservation Center, Koror, Palau. Thus, voucher specimens are not listed for several shallow-water 
TABLE 1

List of All Crinoids Known from Palauan Waters, with Recorded Depths (m)

\begin{tabular}{|c|c|c|c|c|c|c|c|c|c|c|c|c|c|c|c|c|c|c|}
\hline \multirow[b]{2}{*}{ Species } & \multirow[b]{2}{*}{1980 Survey } & \multicolumn{13}{|c|}{2002 Shallow-Water Survey Sites } & \multicolumn{4}{|c|}{2001 Submersible Sites } \\
\hline & & 1 & 2 & 3 & 4 & 6 & 8 & 9 & 10 & 11 & 12 & 13 & 14 & 15 & $\mathrm{U}-1$ & S-D & M-2 & $M-3$ \\
\hline \multicolumn{19}{|l|}{ Antedonidae } \\
\hline Dorometra nana & $\mathrm{X}$ & & & & & 1 & 7 & & & & & & & 5 & & & & \\
\hline Charitometridae & & & & & & & & & & & & & & & & & & \\
\hline Glyptometra sp. & & & & & & & & & & & & & & & & & & 226 \\
\hline \multicolumn{19}{|l|}{ Colobometridae } \\
\hline Cenometra bella & $4-5$ & $11-14$ & 20 & $\mathrm{X}$ & $X$ & & & & 24 & & $X$ & & & & & & & \\
\hline Cyllometra manca & $180-300$ & & & & & & & & & & & & & & $109-120$ & 101 & 146 & \\
\hline Oligometra serripinna & $\mathrm{X}$ & & & & & & & & $20-27$ & 0 & & & & & & & & \\
\hline \multirow{2}{*}{\multicolumn{19}{|c|}{ Comasteridae }} \\
\hline & & & & & & & & & & & & & & & & & & \\
\hline Comaster schlegelii & $X$ & 20 & $5-6$ & & & & & 2 & & & 10 & & & $5-8$ & & & & \\
\hline Clarkcomanthus littoralis & & & & & & 4 & & & & & 9 & & & $4-8$ & & & & \\
\hline $\begin{array}{l}\text { Clarkcomantbus luteofuscum } \\
\text { Comanthus alternans }\end{array}$ & $\begin{array}{l}2-5 \\
10-22\end{array}$ & 20 & & & & & & & & & & & & $5-8$ & & & & \\
\hline Comanthus parvicirrus & $\mathrm{X}$ & & & & 13 & & 21 & & & & & & & 4 & & & & \\
\hline Comanthus suavia & & & & & & & & 2 & 8 & & $8-17$ & & & & & & & \\
\hline Oxycomanthus bennetti & $2-10$ & & $4-20$ & $<5$ & $2-4$ & & & $1-2$ & 3 & & $10-11$ & & & & & & & \\
\hline Oxycomanthus bennetti (deep) & $>15-40$ & & & & 25 & & & & & & & & & $1-3$ & & & & \\
\hline Oxycomanthus comanthipinna & & & & & & & & & 9 & & & & & $4-5$ & & & & \\
\hline Oxycomantbus exilis & & & & & & & 12 & & & & & & & $4-8$ & & & & \\
\hline Capillaster cf. multiradiatus & $2-3$ & & & & & 1 & & & & & & & $3-16$ & & & & & \\
\hline Pbanogenia gracilis & $\mathrm{X}$ & & & $<5$ & 7 & $3-17$ & $<6-17$ & 2 & & & $10-11$ & & & 5 & & & & \\
\hline Alloeocomatella pectinifera & & & & & & & & & & & & & 5 & 8 & & & & \\
\hline Alloeocomatella polycladia & & & & & & & & & & & 17 & & & & & & & \\
\hline Comatella nigra & $\mathrm{X}$ & & & & & & 7 & & & & & & & 5 & & & & \\
\hline Palaeocomatella difficilis & & & & & & & & & & & & & & & & & 219 & \\
\hline \multicolumn{19}{|l|}{ Eudiocrinidae } \\
\hline Eudiocrinus venustulus & & & & & & & & & & & & & & & 120 & & & \\
\hline \multicolumn{19}{|l|}{ Mariametridae } \\
\hline Dichrometra flagellata & $\mathrm{X}$ & & & & & & & & & & & & $3-11$ & & & & & \\
\hline Lamprometra palmata & 0.3 & & & & & 1 & & & & & & 1 & & & & & & \\
\hline Stephanometra indica & $\mathrm{X}$ & & & & & & & & & & $13-15$ & & & & & & & \\
\hline \multirow{2}{*}{\multicolumn{19}{|c|}{ Thalassometridae }} \\
\hline & & & & & & & & & & & & & & & & & & \\
\hline Cosmiometra belsuchel, n. sp. & & & & & & & & & & & & & & & & & $183-253$ & \\
\hline \multicolumn{19}{|l|}{ Phrynocrinidae } \\
\hline Porphyrocrinus verrucosus & & & & & & & & & & & & & & & & & 218 & $238-310$ \\
\hline
\end{tabular}

Note: Depths listed for Meyer and Macurda (1980) are those few specified in their text. X, no depth recorded. See text for localities of 2001-2002 survey sites. For submersible sites, U, Uchelbeluu; S-D, Short Drop-off; M, Mutremdiu. 
taxa. However, Table 1 includes all depth and locality records. Citations for authorship of taxonomic names are not included in the literature cited. Other abbreviations: ZMA, Zoölogisch Museum, Amsterdam; AUm, Australian Museum, Sydney.

\section{RESULTS}

Table 1 lists all crinoid species currently known from Palauan waters. Location and depth of collection are given for the 2002 survey. The 22 species recorded by Meyer and Macurda (1980), including the deeperwater colobometrid Cyllometra manca, have been reduced to 18 by synonymy and revision of several taxa. The 2002 scuba survey found every one of the shallow-water taxa except Clarkcomanthus luteofuscum as well as four additional species. In addition to recollecting C. manca, the submersible survey added five more comatulids and the first stalked crinoid recorded from Palauan waters. Remarks include information modifying or updating Meyer and Macurda (1980).

\section{Family Antedonidae Norman, 1865}

\section{Dorometra nana (Hartlaub, 1890)}

REMARKs: Meyer and Macurda (1980) found up to 20 individuals together under coral or in rubble, but the 2002 survey found only three isolated specimens. Color patterns include solid dark red (both surveys); white with dark brown visceral mass; dark purplish brown with broken orange aboral arm stripe, 1-2 short white arm bands, and some pinnules yellow-banded (2002 survey).

\section{Family Charitometridae}

A. H. Clark, 1909

\section{Glyptometra sp.}

VOUCHER SPECIMEN: CRECH 152, $\mathrm{Mu}-$ tremdiu 3, $226 \mathrm{~m}$, no habitat data.

remarks: The first record of the Charitometridae from Palauan waters. Gold colored in life. Of the 15 nominal species in Glyptometra, CRECH 152 approaches G. crassa (A. H. Clark, 1912) and G. inaequalis (Car- penter, 1888) in having longest cirrus segments about as long as wide or slightly longer and of similar width throughout (A. H. Clark 1950). However, it differs in several important ways from each. It is not treated as a new taxon here because variation in the genus is poorly understood, several nominal species are poorly distinguished, several diagnostic characters are inconsistently applied, and G. crassa may include more than one species (see A. H. Clark 1950). СRECH 152 is similar to the holotype of G. crassa in having cirri of similar lengths and numbers of segments (up to 34 versus $32 \mathrm{~mm}$; up to 20 segments) with the longest proximal segments (c6-8) slightly longer than wide and the distal segments all shorter than wide with distal aboral tubercles (A. H. Clark 1950). However, although both specimens have similar arm lengths (180 $\mathrm{mm}$ in G. crassa; $190 \mathrm{~mm}$ in CRECH 152), CRECH 152 has twice as many arms (21 versus $10-11)$, more cirri (36 versus $25)$ in 15 rather than 10 columns, and brachitaxial ossicles with a well-developed midaboral knob or tubercle lacking in G. crassa (A. H. Clark 1912). Other specimens included within $G$. crassa, in particular the type of Perissometra gorgonia A. H. Clark, 1916, agree with CRECH 152 in having brachitaxial ossicles flat-sided and apposed with weakly raised lateral edges and with a prominent midaboral knob or rounded oval ridge (A. H. Clark 1950; C.G.M., pers. obs.). However, some differ in having aborally smooth cirri, $\mathrm{Ibr}_{1}$ tuberculate rather than smooth with a midaboral knob, the $\mathrm{IIBr}$ series of mostly two rather than four ossicles (though this varies in some other charitometrids), and the proximal brachials with prominently thickened or everted distal margins rather than smooth ones. The long oral pinnules in CRECH 152 (up to $19 \mathrm{~mm}$ long with 51 short segments) have not been described in any similarly sized G. crassa.

Glyptometra inaequalis may have cirri in 15 columns as in CRECH 152, but the cirri are aborally carinate, the IIBr series are composed of four ossicles (with a syzygy at $\left.\mathrm{IIbr}_{3+4}\right)$, and the first syzygy on arms arising from IIBr2 is usually at $b_{1+2}$ rather than $\mathrm{br}_{3+4}$. Also, although G. crassa is known from 
Indonesia at depths similar to that of the Palauan specimen (245-487 m), G. inaequalis was collected in 1,152-1,187 m from Fiji south to New Zealand (with one Philippine record).

Family Colob ometridae A. H. Clark, 1909

\section{Cenometra bella (Hartlaub, 1890)}

Remarks: Meyer and Macurda (1980) recorded $C$. bella as shallow as $3 \mathrm{~m}$. In 2002, one to eight individuals per dive were found only in $>10 \mathrm{~m}$, chiefly clinging to unidentified sea whips (octocoral fans at site 12).

\section{Cyllometra manca (Carpenter, 1888)}

VOUCHER SPECIMENS: CRECH 104A，105, 106, 107, Uchelbeluu 1, $120 \mathrm{~m}$, on antipatharians (Pteridopathes pinnata); CRECH 111, Short Drop-off, $101 \mathrm{~m}$, no habitat data; CRECH 112, 114, Uchelbeluu 1, 109-111 m, on the octocoral Viminella sp.; CRECH 139, Mutremdiu 2, $146 \mathrm{~m}$, no habitat data; CRECH 165, Mutremdiu 2, no depth recorded, no habitat data.

REMARKs: Meyer and Macurda (1980) recorded one specimen recovered from a Nautilus trap brought up from 180-300 $\mathrm{m}$ on the escarpment at Bailechesengel. Most specimens collected in 2001 agree with A. H. Clark's (1947) description: 12-26 arms (ray length $[\mathrm{R}]=50-100 \mathrm{~mm}$ ); brachitaxes of two ossicles each; cirri chiefly short (most $\leq 12 \mathrm{~mm}$ long, but one with cirri to $21 \mathrm{~mm}$ ), with fewer than 40 short segments, the majority with paired spines; $\mathrm{P}_{2}$ longer and more robust than $\mathrm{P}_{1}$, and genital pinnules not expanded. Four smaller specimens (CRECH 107, $111,112,165 ; \mathrm{R}=25-50 \mathrm{~mm}$ ) differ in having only 10 arms, most proximal cirrus segments with a transverse ridge rather than paired spines, and $\mathrm{P}_{2}$ little if at all more robust than $\mathrm{P}_{1}$. Most were collected with typical larger $C$. manca. Figure 2 illustrates the wide range in variation of arm number versus arm length recorded for this species. The Palau specimens fall within the known range recorded by A. H. Clark (1947), as well as within the depth range previously recorded for most specimens (90-200 m) (A. H. Clark 1947).

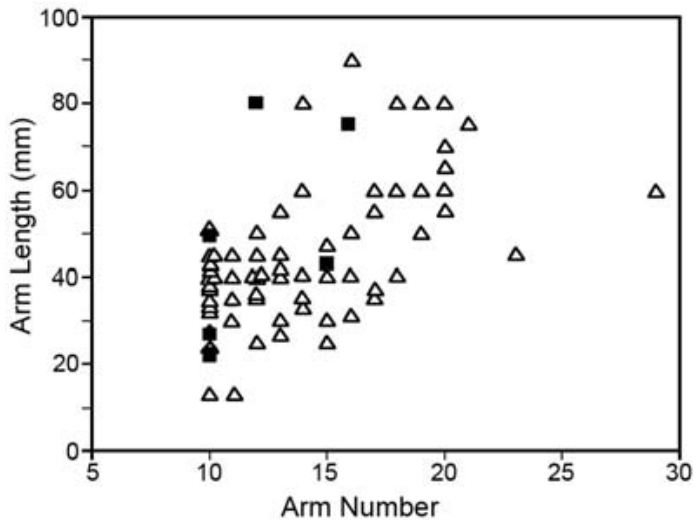

FIgURE 2. Relationship between arm number and arm length in Cyllometra manca recorded by A. H. Clark $(1947)(\triangle)$ and in the current study $(\mathbf{\square})$.

\section{Oligometra serripinna (Carpenter, 1881)}

REMARKS: Uncommon in both surveys; two specimens were found in 2002 clinging near the bases of octocoral fans in $20-27 \mathrm{~m}$.

\section{Pontiometra andersoni (Carpenter, 1889)}

VOUCHER SPECIMEN: CRECH 175, site 11 , $9 \mathrm{~m}$, on side of pinnacle.

REMARKS: Meyer and Macurda (1980) reported this species as widespread and most abundant on inner reefs, especially along passes in 3-6 m. However, the 2002 survey recorded only a single specimen. Its large size, characteristic parabolic fan posture, and occurrence on prominent perches suggest that it was not overlooked in 2002 but may have suffered a substantial population decline.

Family Comasteridae A. H. Clark, 1908 Subfamily Comasterinae A. H. Clark, 1908

\section{Comaster schlegelii (Carpenter, 1881)}

VOUCHER SPECIMENS: CRECH 176, site 2, 4.5-6 $\mathrm{m}$, on reef slope.

REMARKS: Usually semicryptic in reef crevices with arms extended in a bushy fan in $<10 \mathrm{~m}$. One individual was found exposed on a quiet rubble and sand bottom (site 1, $20 \mathrm{~m}$ ), with arms curled in a loose meridional pos- 
ture. Two specimens (sites 3,12) exhibited some features of Comaster audax Rowe et al., 1986: $<5$ fully developed cirri and at least middle brachials with everted distal margins. One also had brachitaxial ossicles with a strong midaboral knob and pinnule combs only as far as $\mathrm{P}_{3}$. However, molecular data (Christopher Owen, pers. comm.) nest these specimens within $C$. schlegelii. The specimens from sites 1,3 , and 12 were not retained as vouchers.

\section{Clarkcomanthus littoralis (Carpenter, 1888)}

VOUCHER SPECIMENS: CRECH 206, 222, site $12,8.5 \mathrm{~m}$.

remarks: A new record for Palau. Semicryptic in crevices or rubble with some arms usually extended in multidirectional posture. In situ colors are black, green, or mottled light and dark green; pinnules may be yellow-banded, -spotted, or -tipped. Close examination usually reveals darker articulations and small yellow or green spots or tiny flecks. Clarkcomanthus littoralis has been confused with Comanthus parvicirrus (Müller, 1841 ); both have $<10$ cirri on a small centrodorsal. Definitive identification requires microscopic examination of oral pinnules.

9. Clarkcomanthus luteofuscum (H. L. Clark, 1915)

remarks: Rowe et al. (1986) noted that Meyer and Macurda (1980) recorded this species as Comanthus samoanus A. H. Clark, 1909. This is the only crinoid recorded by them not found in the current survey. Kirkendale and Messing (2003) mistakenly referred the 1980 record to Comanthus wablbergii (Müller, 1843).

\section{Comanthus alternans (Carpenter, 1881)}

remarks: Reported by Meyer and Macurda (1980) as Comantheria briareus (Bell, 1882) and Comantheria sp. cf. C. briareus. The former was black in situ (or with yellow pinnule tips), with $>80$ arms up to $10 \mathrm{~cm}$ long; found chiefly in the southern part of their survey area in $\leq 12 \mathrm{~m}$. Closely spaced individuals sometimes formed common filtra- tion fans. The latter was chiefly white in situ, with $>100$ arms up to $15 \mathrm{~cm}$ long; found only at Bailechesengel I. in $>15 \mathrm{~m}$, a site not visited in 2002. C.G.M. (unpubl. data) and Meyer and Macurda (1980) observed both at Madang, Papua New Guinea, and Australia, respectively. No robust morphological features distinguish these forms as separate taxa, and Rowe et al. (1986) recognized both as $C$. alternans. In addition to its usual occurrence on coral heads and pinnacles chiefly in $<10 \mathrm{~m}$, several specimens were found in 2002 with $C$. schlegelii (site $1,20 \mathrm{~m}$ ) in a balllike meridional posture on a quiet rubble and sediment bottom.

\section{Comantbus parvicirrus (Müller, 1841)}

REMARKs: Semicryptic with arms extended in a multidirectional posture from under ledges and crevices in 4-21 m. Colors chiefly blue gray or green gray (often black or green in situ), with pinnules red purple or blue with yellow tips and a white stripe. Previous descriptions included several taxa now considered distinct (Rowe et al. 1986): Oxycomanthus perplexum (H. L. Clark, 1916); Clarkcomanthus albinotus Rowe et al., 1986; Comanthus gisleni Rowe et al., 1986; Comanthus suavia Rowe et al., 1986; Clarkcomanthus littoralis (Carpenter, 1888); and Oxycomanthus comanthipinna (Gislén, 1922). The latter three are now also known from Palau.

\section{Comanthus suavia Rowe et al., 1986}

Remarks: Posture as in C. parvicirrus. Collected or observed in 3-17 m. Color gray in situ with yellow pinnule tips, but arms actually gray with black articulations. Centrodorsal usually yellow. Fig. $6 g$ in Meyer and Macurda (1980), identified as Comanthus parvicirrus, may represent this species, although C. suavia usually lacks cirri and the figured specimen bears one.

\section{Oxycomanthus bennetti (Müller, 1841)}

remarks: Reported as Comanthus bennetti by Meyer and Macurda (1980). It is unclear if two recognizable forms represent separate 
species or ecophenotypes: (1) variably colored (orange, black, green, yellow, or a combination), with 60-80 arms $<20 \mathrm{~cm}$ long; common to abundant in $<15 \mathrm{~m}$ (rarely to $20 \mathrm{~m}$ ); (2) gray in situ with fewer longer arms $(>20$ $\mathrm{cm})$; rare and isolated, usually in $>20 \mathrm{~m}$. Meyer and Macurda (1980) reported the latter in $>15$ to $40 \mathrm{~m}$. The 2002 survey found two small specimens of the first form, one with only $\sim 16$ arms, incompletely exposed (unlike the completely exposed adults) under edges of dead Acropora tables.

\section{Oxycomanthus comanthipinna (Gislén, 1922)}

VOUCHER SPECIMENS: CRECH 184, 187 , site 15 .

remarks: A new record for Palau. Semicryptic, with calyx hidden within rubble and extending one or more arms in a multidirectional posture. Found only at site 15 in 4-6 $\mathrm{m}$. In situ colors orange or green with dark zebra stripes or all yellow; pinnules yellow and brown with blue tips; disk yellow with a reticulation of fine brown lines or dots. Fig. $4 f$ in Meyer and Macurda (1980) might be this species.

\section{Oxycomanthus exilis Rowe et al., 1986}

VOUCHER SPECIMENS: CRECH 218 , site 15 , $4 \mathrm{~m}$; CRECH 249 , site $15,12 \mathrm{~m}$.

remarks: A new record for Palau, although these may be small, less-mature specimens of the previous species (see Rowe et al. 1986). Cryptic, at least during the day, in crevices or under rubble with arms curled. Found only at sites 8 and 15 . In situ colors orange with dark zebra stripes or gray. Arms with a pale midaboral stripe; pinnules orange or dark brown with yellow or purple tips.

\section{Subfamily Capillasterinae} A. H. Clark, 1909

\section{Capillaster cf. multiradiatus (Linnaeus, 1758)}

VOUCHER SPECIMENS: CRECH 189, 200, 214, 226, site $14,4.5-16 \mathrm{~m}$.

REMARKs: Cryptic during the day and semicryptic at night among coral branches or in crevices with arms forming monoplanar arm fans (Meyer and Macurda 1980). Found to a depth of $16 \mathrm{~m}$ but often abundant in $3-$ $10 \mathrm{~m}$ (site 14) or as little as $1 \mathrm{~m}$ (site 5). Meyer and Macurda (1980) recorded it in as little as $2 \mathrm{~m}$. In situ color banded brown, tan, or red brown and white (rarely all brown). Identification is tentative because specimens from elsewhere differ in color and behavior. At Madang, Papua New Guinea (C.G.M., unpubl. data), C. multiradiatus is tan or dark brown with brown and white pinnules, and occurs no shallower than $8 \mathrm{~m}$. During the day, it is cryptic or semicryptic with arms extended from sponges or foliaceous or branching corals. In $>25 \mathrm{~m}$, it may be completely exposed on octocoral fans or whips and usually forms an irregular radial fan with several arms curled. At Palawan I., Philippines, it has brown, green, or white arms with dark articulations and was found during the day in 17-20 m exposed on corals with arms coiled, and semicryptic in a sponge with arms in a multidirectional posture (Messing [1994] and unpubl. data). No detailed morphological comparisons have yet been made.

\section{Subfamily Phanogenimae} White et al., 2001

\section{Phanogenia gracilis (Hartlaub, 1893)}

VOUCHER SPECIMENS: CRECH 205, 244, 247 , site $3,<5 \mathrm{~m}$, under pinnacle overhangs on reef slope; СRECH 181,211, site 6, 5-8 m, arms curled in crevices and under ledges; CRECH 188,245 , site $6,3-4 \mathrm{~m}$, curled in shallow crevices on reef-top spurs; CRECH 219, site 6, 4-17 m, arms extending from crevices; CRECH 186, 224, 210, 235, site 12, 10-11 m, all deep within crevices, under ledges, or among coral branches.

REMARKs: Widely reported as two separate taxa-Comaster gracilis and Comaster multifidus (Müller, 1841) (Gislén 1940, A. M. Clark and Davies 1965, A. M. Clark and Rowe 1971, A. M. Clark 1972, Meyer and Macurda 1980, Zmarzly 1984, 1985, Meyer 1986, Bradbury et al. 1987, Vail 1987, Chen et al. 1988, Stephens 1989, and Messing 
1994). See Messing (1998b) for a recent revision. Two forms of $P$. gracilis occur at Palau: (1) arms numerous (up to $\sim 120$ ) but short (usually $<12 \mathrm{~cm}$ ), curled under overhangs on reef tops or cryptic (usually in $2-5 \mathrm{~m}$, occasionally to $10 \mathrm{~m}$ ); (2) arms fewer (usually $<60$ ) with anterior arms (up to $\sim 25 \mathrm{~cm}$ ) much longer than posterior arms and semicryptic with arms extended in a multidirectional posture, usually in $>6 \mathrm{~m}$. Although both forms occasionally occur together, morphological and molecular analyses reveal no consistent distinctions apart from arm length and number, which vary with growth (C. Owen, pers. comm.).

18. Alloeocomatella pectinifera (A. H. Clark, 1911)

VOUCHER SPECIMENS: CRECH 236, site 15 (juv.), $8 \mathrm{~m}$, under rubble.

remarks: A new record for Palau. Cryptic during the day; at night, several of its 10 arms extend upward from among coral branches or rubble. Anterior arms much longer than posterior (sometimes $>30 \mathrm{~cm}$ ), even in juveniles; pinnules orient in a single plane. Color solid red. Two specimens were collected in $5 \mathrm{~m}$. A third very small specimen may belong to the following species.

\section{Alloeocomatella polycladia Messing, 1995}

VOUCHER SPECIMENS: CRECH 195, site 12 . REMARKs: Recorded as Comatella maculata (Carpenter, 1888) by Meyer and Macurda (1980). A single specimen was found curled up under a dead Acropora plate in $17 \mathrm{~m}$. Its dark red color appears black in situ. Unlike $A$. pectinifera, all arms are about the same length. Although not observed at night at Palau, elsewhere $A$. polycladia emerges partly or completely, with arms held in a more or less arcuate fan and pinnules oriented in a single plane (Messing 1995).

\section{Comatella nigra (Carpenter, 1888)}

remarks: Cryptic during the day under rubble and ledges. Meyer and Macurda (1980) reported this species as extending its arms in a multidirectional posture from reef recesses. Uncommon in both surveys.

\section{Palaeocomatella diffcilis (Carpenter, 1888)}

VOUCHER SPECIMENS: CRECH $120, \mathrm{Mu}-$ tremdiu 2, no depth or substrate recorded; CRECH 161, Mutremdiu 2, on antipatharian, $219 \mathrm{~m}$.

remarks: A new record for Palau. Color in life white with numerous short orange brown arm bands and a gray disk (pink in situ). Messing (2001) recognized three species of Palaeocomatella: P. difficilis from Indonesia and the Philippines; P. biwia McKnight, 1977, from New Zealand, the Kermadec Islands, and Indonesia (Messing et al. 2000), and P. decora (A. H. Clark, 1912) from the Loyalty Ridge (Southwest Pacific) and East China Sea. A transversely oriented first comb tooth distinguishes $P$. decora, and placement of proximal arm syzygies distinguishes $P$. difficilis from P. biwia. However, because the latter appears to be a variable character, and most specimens are fragmentary, it is not clear that these two are distinct. The holotype of $P$. difficilis (Natural History Museum, London, cat. no. 1888.11.9.101) bears br $_{1+2,3+4}$ together on its few remaining arms (Hoggett and Rowe 1986, Messing 2001), whereas the first syzygy in the holotype of $P$. hiwia (New Zealand Oceanographic Inst. cat. no. H219) occurs at $\mathrm{br}_{3+4}$ on exterior arms and at $\mathrm{br}_{1+2}$ on interior arms. Messing et al. (2000) found similar distinctions among specimens from Indonesia. However, although the two $\mathrm{Pa}$ lauan specimens clearly belong to the same taXon, CRECH 161 has interior arms with $\mathrm{br}_{1+2}$ alone and exterior arms with $\mathrm{br}_{3+4}$, as in $P$. biwia, and CRECH 120 has some interior arms with $\mathrm{br}_{1+2,3+4}$ as in $P$. difficilis. In addition, the Palauan specimens were collected in 219 $\mathrm{m}$ and 107-210 m, overlapping if not completely within the bathymetric range of $P$. difficilis $(205-275 \mathrm{~m})$ but shallower than the type material of $P$. hiwia (542 to at least $808 \mathrm{~m}$ ). The specimens are therefore attributed to the senior taxon.

Both Palauan specimens have ripe gonads. CRECH 161 has 26 arms with $\mathrm{R}=68-78 \mathrm{~mm}$ and 47 cirri of 12-16 segments. CRECH 120 
has 28 arms with $\mathrm{R}=40 \mathrm{~mm}$, and $\sim 31$ cirri of up to 17 segments. The habit, posture, and overall morphology closely resemble those of Neocomatella alata (Pourtalès, 1878) from the tropical western Atlantic.

$$
\text { Family Eudiocrinidae A. H. Clark, } 1907
$$

22. Eudiocrinus venustulus A. H. Clark, 1912

VOUCHER SPECIMEN: CRECH 104, Uchelbeluu 1, on antipatharian (Pteridopathes pinnata), $120 \mathrm{~m}$.

REMARKS: The first record of the Eudiocrinidae from Palau. The specimen agrees with the description of E. venustulus (A. H. Clark, 1941): centrodorsal diameter $0.8 \mathrm{~mm}$; $\mathrm{R}=40 \mathrm{~mm}$; cirri $\mathrm{XV}$, up to $3.5 \mathrm{~mm}$ long, of 11-13 segments, most with strongly expanded distal margins; radials covered with small tubercles or beads; several proximal ray ossicles with a strong midaboral tubercle or thickening (proximal on $\mathrm{Ibr}_{1}$ and distal on $\mathrm{Ibr}_{2}, \mathrm{br}_{2}$, and $\mathrm{br}_{4}$ ); first two segments of proximal pair of pinnules with a prominent keel. These are weaker than the large, fan-shaped carinate processes described for the holotype but may reflect the smaller size of the Palau specimen. Eudiocrinus venustulus was previously known from the Philippines and Indonesia in 73-112 m (A. H. Clark 1941).

Family Mariametridae A. H. Clark, 1909

\section{Dichrometra flagellata (Müller, 1841)}

VOUCHER SPECIMENS: CRECH 190, 197, 199, 201, 202, 203, 204, 212, 216, 229, 230, site $14,5-11 \mathrm{~m}$, chiefly exposed on coral heads.

REMARKs: Abundant at night at site 14 in 3-10 m. Several specimens approach Liparometra articulata (Müller, 1847) in having $\mathrm{P}_{2}$ and $\mathrm{P}_{3}$ of similar length and robustness on at least some arms, rather than with $\mathrm{P}_{3}$ longer and more robust, as diagnostic of Dichrometra. No consistent color or habitat differences distinguish these forms. Such variations suggest that these two species may be synonymous and, consequently, that Dichrometra and Liparometra do not warrant separate generic status.

\section{Lamprometra palmata (Müller, 1841)}

VOUCHER SPECIMENS: CRECH 239, site 12; CRECH 217, 221, site 13 .

REMARKs: Two forms may represent separate taxa: (1) $P_{2}$ larger than $P_{1}$ and $P_{3}$; variously banded with orange, brown, purplish gray, and white, often with dark brown blotches on ray bases; (2) $\mathrm{P}_{2}$ enormously enlarged relative to $\mathrm{P}_{1}$ and $\mathrm{P}_{3}$; concentrically banded with green or greenish brown and white. The latter is consistent with Lamprometra brachypecha H. L. Clark, 1915, which A. H. Clark (1941) treated as a synonym of L. palmata. The first was common among branching corals in a macroalgae and seagrass bed in $1 \mathrm{~m}$ (site 5). Though usually cryptic during the day, both forms were found exposed, forming irregular radial fans in strong flow on the tunnel floor at site 13 . Distinctions between the two have not been examined in detail.

\section{Stephanometra indica (Smith, 1876)}

VOUCHER SPECIMENS: CRECH 185, 227, site 12, 13-15 m, under dead and living coral.

remarks: Rowe and Gates (1995) and Rankin (2000) synonymized Stephanometra spicata (Carpenter, 1881) and S. oxyacantha (Hartlaub, 1890), respectively, under $S$. indi$c a$. The three had been distinguished by an increasing number of enlarged, stiffened oral pinnules, from $\mathrm{P}_{2}$ in $S$. indica to $\mathrm{P}_{4-5}$ in $S$. oxyacantha. Meyer and Macurda (1980) noted that specimens of $S$. indica were also usually smaller and might be immature. The two surveys recorded both indica and oxyacantha forms at Palau, though Meyer and Macurda (1980) noted one specimen that approached the spicata form.

26. Stephanometra tenuipinna (Hartlaub, 1890)

VOUCHER SPECIMENS: CRECH 213 , site 14 , 12 m, under Acropora table.

remarks: Treated as S. echinus (A. H. Clark, 1908) by Meyer and Macurda (1980). Rankin (2000) synonymized S. echinus under S. tenuipinna. The pink- and maroon-banded arms of the two specimens collected in 2002 
differ somewhat from the color patterns reported by Meyer and Macurda (1980).

\section{Family Thalassometridae \\ A. H. Clark, 1908}

27. Cosmiometra belsuchel Messing, n. sp.

Figure $3 a$

VOUCHER SPECIMENS: USNM 1090975 (holotype), Mutremdiu 2, $253 \mathrm{~m}$, on bamboo octocoral Keratoisis sp. (Isididae); USNM
1091044 (paratype), Mutremdiu 2, 183-253 $\mathrm{m}$, on antipatharian (Parantipathes tenuispina). DIAGNOSIS: A species of Cosmiometra A. H. Clark with arms 20; cirri in 10 columns of 2-4 (usually 3) sockets, with up to $66 \mathrm{seg}$ ments; distal cirral spines with triangular distal face bordered with irregular marginal teeth; lateral portions of brachitaxial and proximal arm ossicles with coarse, partly coalesced spiny tubercles.

DESCRIPTION OF THE holotyPe: Centrodorsal truncated conical, $4.0 \mathrm{~mm}$ across, with radial margin deeply incised; DH 1.3

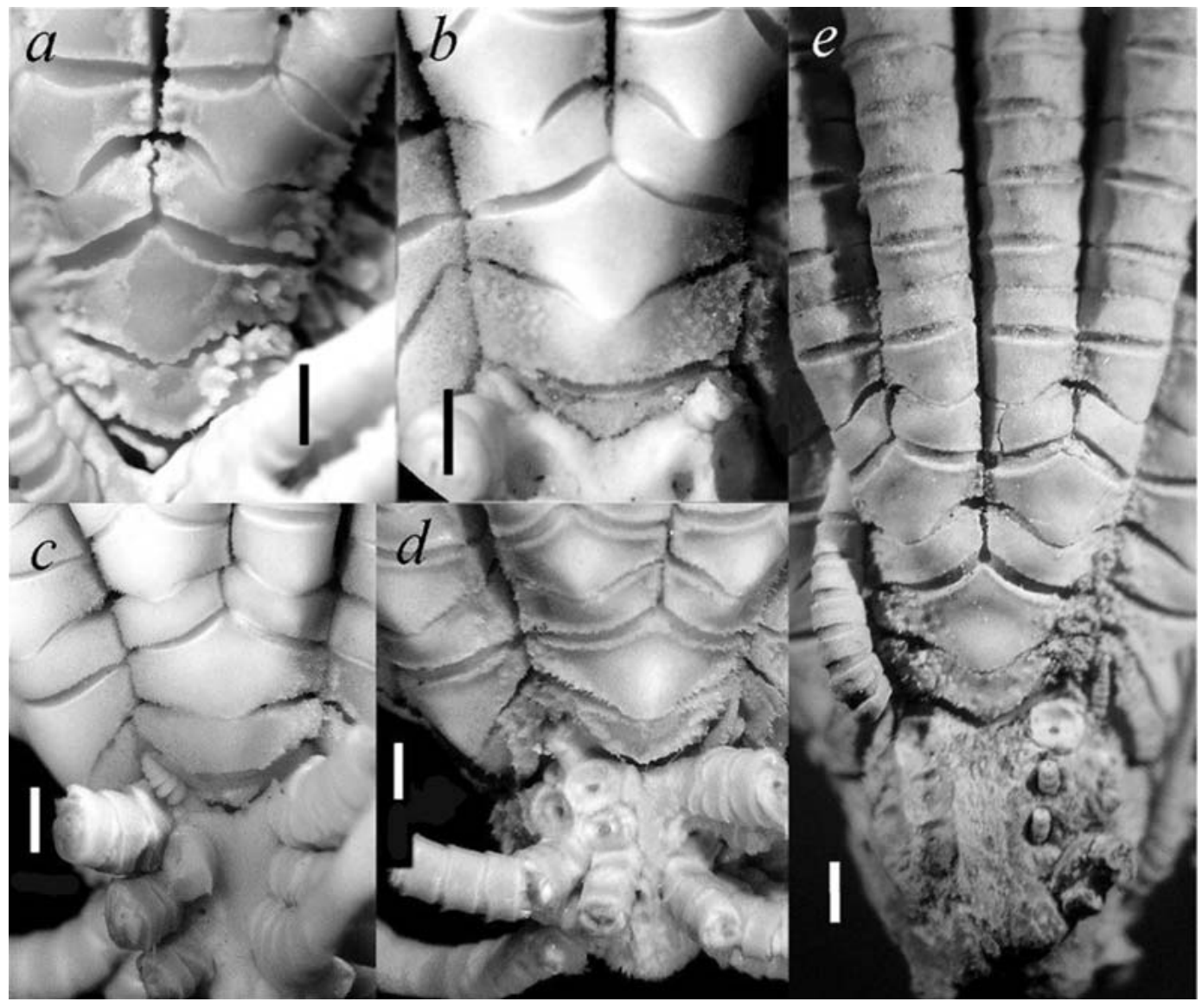

Figure 3. Bases of rays of holotypes of Cosmiometra spp. $a$, C. belsuchel Messing, n. sp. $b$, C. helene A. H. Clark (zMA E2025) (= C. philippinensis). $c$, C. philippinensis A. H. Clark (usnm 27497). d, Thalassometra komachi A. H. Clark [= C. aster (A. H. Clark)] (Usnm 22696). e, Cosmiometra dasybrachia H. L. Clark (aum E4746). Note: mottling in 3a due to partial drying of specimen. Scale bars $=1 \mathrm{~mm}$. 
(ratio of centrodorsal diameter to height). Polar area irregularly spinose, $1.8 \mathrm{~mm}$ across. Cirri XXX, 52-66, up to $43 \mathrm{~mm}$ long, in 10 columns of 2-4 sockets (chiefly 3 ) separated midradially by triangular area. $\mathrm{C} 1-3$ or $1-4$ short, round to oval in cross section; aboral surface or distal margin of c2-3 irregularly spiny; following cirrals compressed; c5-6 longest, smooth, with LW 1.4-1.5 [ratio of axial length (L) to transverse width (W)]; following cirrals rapidly decreasing in length, shorter than wide in distal half of cirrus. Aboral spine first appearing on c9-11, gradually occupying all or most of aboral margin. Distal spines tall and narrow; proximal margin curved; distal face flat, triangular, with irregular marginal teeth. Opposing spine larger than those preceding.

Radials concealed. Ibr ${ }_{1}$ short, LW 3.3, shallowly V-shaped, with irregular, partly coalesced spiny tubercles covering at least lateral thirds; ornamentation continuing to proximal 2-3 brachials but progressively more restricted to lateral margins; lateral portion of distal and proximal margins of these ossicles sometimes raised (Figure $3 a$ ). $\mathrm{Ibr}_{2}$ axil hexagonal with diverging lateral margins; lateral thirds of proximal and distal margins parallel; LW 1.7; proximal margin sometimes weakly dentate. $\mathrm{IIBr} 2$ series similar to $\mathrm{IBr} 2$ series but with relatively longer ossicles; $\mathrm{LW}$ of $\mathrm{IIbr}_{2}$ axil 1.55. Arms 20; R = 88; br r $_{1}$ rectangular, LW 2.0; $\mathrm{br}_{2}$ with proximal synarthrial projection, $\mathrm{LW} 1.5$; $\mathrm{br}_{3+4} 1.3 \mathrm{~mm}$ across; $\mathrm{br}_{4}$ and following ossicles with fine aboral axial ridges, becoming stronger with spiny distal overlapping tips on distal brachials. $\mathrm{P}_{1}$ with up to 28 prismatic segments, $12 \mathrm{~mm}$ long; all segments smooth or with minute spines along edges, of about equal length with proximal segments squarish and distal segments longer than wide. Following pinnules decreasing in length; middle pinnules 5 $\mathrm{mm}$ long, of 12-13 segments of about equal length; distal segments weakly spiny along edges. Color in life orange brown with white articulations.

DESCRIPTION OF THE PARATYPE: Slightly smaller than the holotype but otherwise similar; $\mathrm{R}=80 \mathrm{~mm}$. Centrodorsal 4.0 $\mathrm{mm}$ across, rounded conical with midradial margin almost straight and small conical spines on convex pole; DH 1.3. Cirri XXXI, up to 65 segments, $32 \mathrm{~mm}$ long. $\mathrm{Ibr}_{1}$ covered with large round and very weakly spiny tubercles except midaborally. $\mathrm{P}_{1}$ proportionally more strongly prismatic and more robust relative to following pinnules than in holotype; of 25 segments.

etymology: The specific epithet, belsuchel, is a Palauan word for ornamented, after the spiny coalescing tubercles on the ray bases of this species. In Palauan, it is pronounced "bel su - ul."

REMARKS: The first record of the Thalassometridae from Palauan waters. Cosmiometra belsuchel Messing, n. sp., approaches the published descriptions of Cosmiometra philippinensis A. H. Clark, 1911; C. aster (A. H. Clark, 1907); and C. dasybrachia H. L. Clark, 1916, in having $\sim 20$ arms and ornamentation restricted to lateral portions of proximal ray ossicles. However, Figure 3 shows that the coarse coalescing tubercles of $C$. belsuchel differ substantially from the numerous tiny spines or clusters of spines in the holotypes of C. philippinensis (USNM 27497) and its synonym C. belene A. H. Clark, 1912 (zMA E2025), and from the raised spinose borders and smooth aboral surfaces (except for some encroachment on $\mathrm{Ibr}_{1}$ ) of ossicles in C. aster. Cosmiometra aster supposedly differs from both $C$. philippinensis and C. belsuchel in having cirri in 15 rather than 10 columns. However, the holotype of Thalassometra komachi (A. H. Clark, 1908), treated as a synonym of $C$. aster by A. H. Clark (1950), also has 10, as does a specimen attributed to $C$. aster by Kogo (1998). In addition, the middle brachials of C. belene are smooth, but those of T. komachi have raised spinose distal margins; both lack the aboral axial ridges of $C$. belsuchel. Thalassometra komachi also has distal brachials with much coarser, toothlike spines. In the holotype of $C$. philippinensis, the bases of the cirri are completely smooth, and the distal aboral spines lack the triangular distal faces of $C$. belsuchel. The holotype of C. dasybrachia $\mathrm{H}$. L. Clark, 1916 (aum E4746) differs from C. belsuchel and the others in having columns of cirrus sockets widely separated midradially and not converging toward the centrodorsal 
apex; cirri of 68-74 segments; and densely spongy and spinose ornamentation more restricted laterally on IBr2 ossicles and reduced to scattered weak, conical spines on the lateral margins of IIBr2 and proximal brachials (Figure $3 e$ ).

Both C. aster and C. philippinensis are bright yellow. Cosmiometra philippinensis is known from the southern Philippines and Indonesia in 245-621 m (A. H. Clark 1950). Cosmiometra aster was originally known from Sagami Bay, Japan, in 180-730 (?740) m (A. H. Clark 1950). More recently, Kogo (1998) and Kogo and Fujita (2005) identified specimens as $C$. aster from Suruga Bay $(425 \mathrm{~m})$, the Izu Islands $(475-520 \mathrm{~m})$, and the Sulu Sea $(730$ $738 \mathrm{~m})$. That material includes specimens larger than those previously described (e.g., centrodorsal diameter $5.0 \mathrm{~mm}$, up to 35 cirri with up to 72 segments). Cosmiometra dasybrachia is known only from Tasmania in 128183 m (A. H. Clark 1950).

Family Phrynocrinidae A. H. Clark, 1907

\section{Porphyrocrinus verrucosus Gislén, 1925}

VOUCHER SPECIMENS: CRECH 144, Mutremdiu 3, $238 \mathrm{~m}$; CRECH 147, Mutremdiu 3, $310 \mathrm{~m}$; CRECH 157, Mutremdiu 2, $218 \mathrm{~m}$.

REMARKs: The first stalked crinoid recorded from Palauan waters. All three specimens attached to the downslope sides of small ( $\sim 0.5 \mathrm{~m}$ high) irregular slump blocks accompanied by larger boulders and smaller rubble on a moderately sloping sedimentcovered bottom, with sediment dammed upslope of the larger blocks. Flow was weak (probably $<10 \mathrm{~cm} \mathrm{sec}^{-1}$ ) and apparently parallel to the slope. Stalks of all three projected outward and upward from the rock faces but not vertically. Rays were arranged in a radial fan with arms slightly recurved into the current. A brief in situ video clip of the specimen with a fully developed crown (CRECH 147) shows what may be long, almost filamentous arm tips lacking pinnules, though these were lost during collection.

Because these specimens differ somewhat from the single known specimen of $P$. verrucosus and from each other, and also exhibit

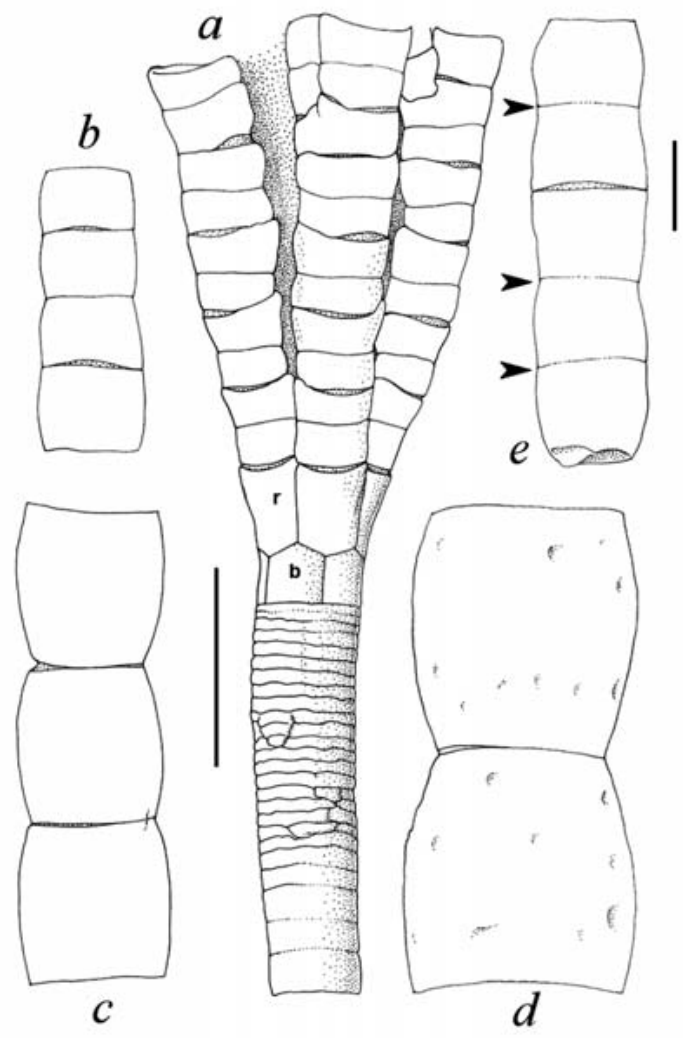

Figure 4. Porphyrocrinus verrucosus Gislén (Crech 147). $a$, Proximal stalk, calyx and base of three rays. $b$, Columnals 28-31. c, Columnals 50-52. d, Columnals 97-98. e, Columnals 128-132, showing ankylosed articulations (arrows). $r$, radial ossicle; b, basal ossicle. Scale bars: lower left $(a-d)$, upper right $(e): 5 \mathrm{~mm}$.

some unusual features, they are described in detail.

CRECH 147 (Figures 4, 5a, 6): Crown of 6 unbranched rays, $2.6 \mathrm{~mm}$ across base of basal circlet; $\mathrm{R} \approx 70 \mathrm{~mm}$ long (measured from base of radial ossicle; tips lost). Calyx (basal and radial circlets) broadening slightly from base; 1.6 times taller than wide across base; sutures between basals and radials visible. Five basals, LW 1.0. Distal diameter of radial circlet 4.0 $\mathrm{mm}$; 6 radials longer than wide, slightly wider distally, with LW 1.3. One radial distinctly narrower than adjacent squarish rather than pentagonal basal. All following brachials shorter than wide; pairs of proximal brachials joined by synostoses $(+)$ : br $1+2,3+4,5+6$, 


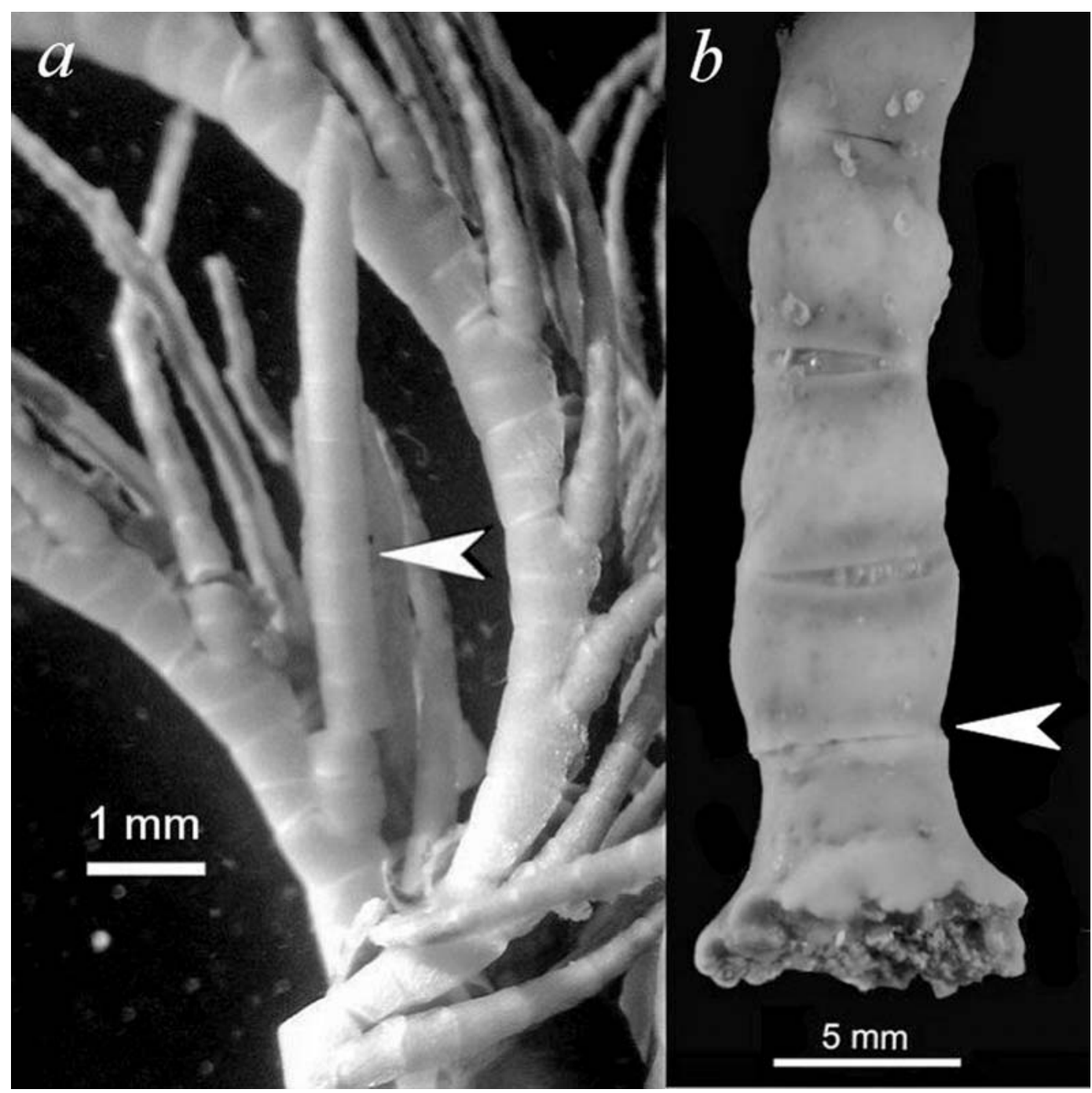

FIGURE 5. Porphyrocrinus verrucosus Gislén. $a$, CRECH 147, portion of arms showing enlarged genital pinnule (arrow); gonad is visible behind tip of arrow. $b$, СRECH 144, base of stalk showing rigid articulation (arrow).

$7+8$, and usually br9+10, with first pinnule on left side of br10; br9 joined to br10+11 by muscular articulation on one ray and bearing first pinnule on left side. No pinnules on brachials with a distal synostosis. Following brachials chiefly with a muscular articulation alternating with a synostosis but sometimes with two muscular articulations in a row (e.g., br12+13, 14, 15+16, 17+18, 19, $20+21, \quad 22+23, \quad 24+25, \quad 26,27+28, \quad 29$,
$30+31$ ). Distal pinnules extremely slender, up to 44 segments, $30 \mathrm{~mm}$ long; first two pinnulars short and wide; following pinnulars rapidly becoming longer than wide and slender. Third pinnule on right side of one ray $\left(\mathrm{P}_{c}\right)$ uniquely much thicker than others and bearing a gonad (Figure 5a) .

Remaining stalk $49.0 \mathrm{~cm}$ long, of $132 \mathrm{col}-$ umnals (in two pieces), decreasing slightly in diameter along proxistele from apex (2.7 


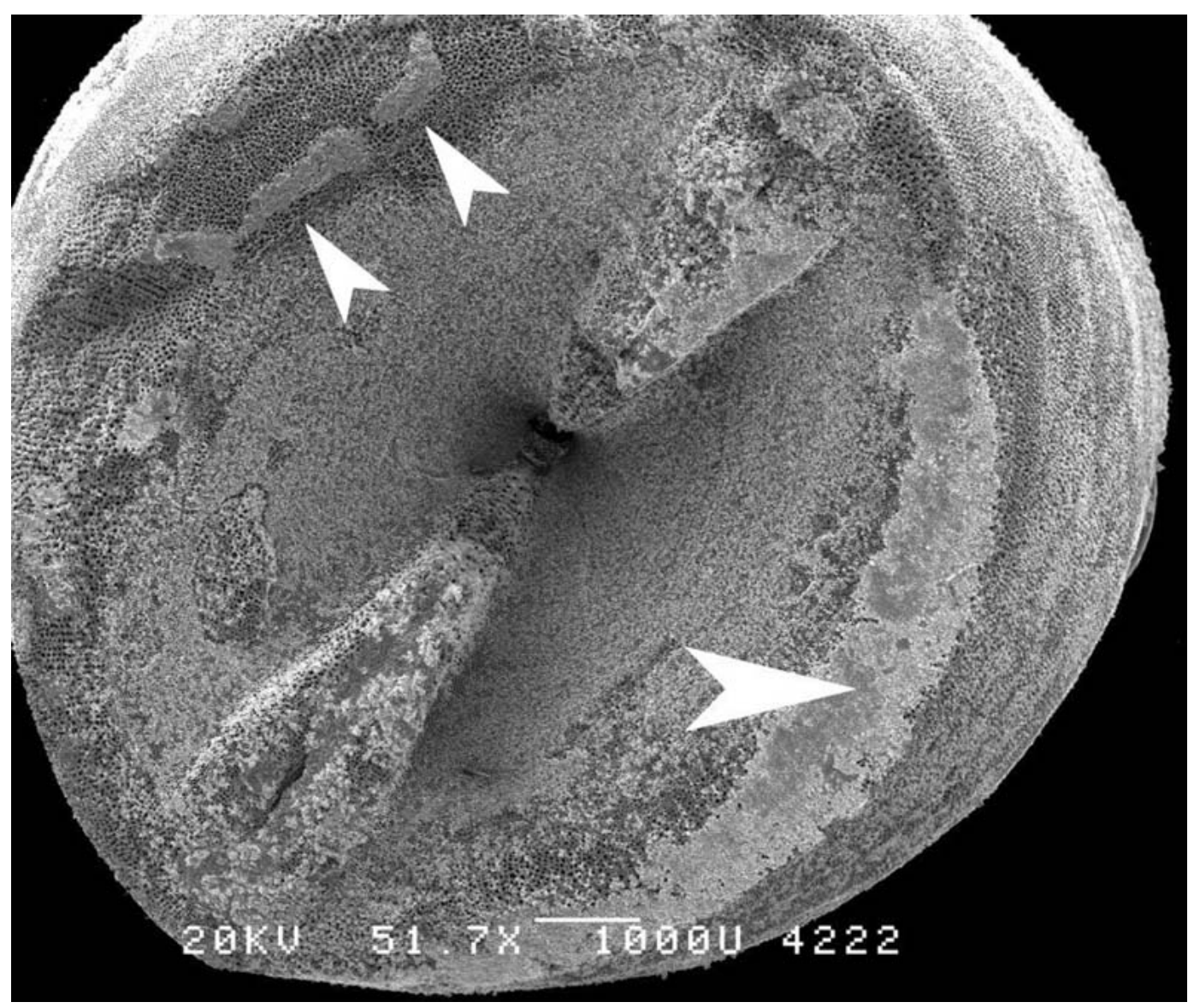

Figure 6. Porphyrocrinus verrucosus Gislén (сREch 147). Scanning electron micrograph of ankylosed distal stalk articular facet showing nonfunctional synarthrial articulation with secondary dense calcite deposited as continuous marginal crescent (large lower arrow), irregular patches (upper small arrows), and small granules on areola and fulcral ridge.

$\mathrm{mm})$ to $23 \mathrm{rd}$ columnal $(2.3 \mathrm{~mm})$ and then gradually increasing (distal diam. $6.2 \mathrm{~mm}$ ). Proximal $\sim 20$ columnals all similarly thin disks tightly sutured; WL $\sim 6.0-9.0$ (ratio of transverse width $[\mathrm{W}]$ to axial length $[\mathrm{L}]$; sutures sometimes indistinct; several thin columnals between 10th and 20th irregularly subdivided by vertical suture(s); columnals subsequently increasing in length, becoming more or less barrel-shaped; 46th and almost all following columnals with $\mathrm{LW} \sim 1.0 ; 25$ th and following columnals joined by synarthry, with 4 scattered pairs joined by ankylosed rigid articulations $(+)$ characterized by areas of dense secondarily deposited calcite (rather than stereom); detached distal stalk fragment of 20 columnals with multiple ankyloses: $119+120,123+124+125,126+127$, $128+129,130+131+132$ (Figures 4e, 6). Distal columnals with numerous shallow, irregular pits. Distal end of stalk and attachment disk lacking.

CRECH 157 (Figure 7a,d-g): Crown of 5 regenerating rays, $3.5 \mathrm{~mm}$ across base; $\mathrm{R}=42 \mathrm{~mm}$ (reconstructed from attached arm base and detached fragment). Five similar pentagonal basals shorter than in previous specimen; LW 0.6. Radials with LW 1.1-1.3, slightly narrower distally so that radial circlet is slightly narrower across than basal circlet; 


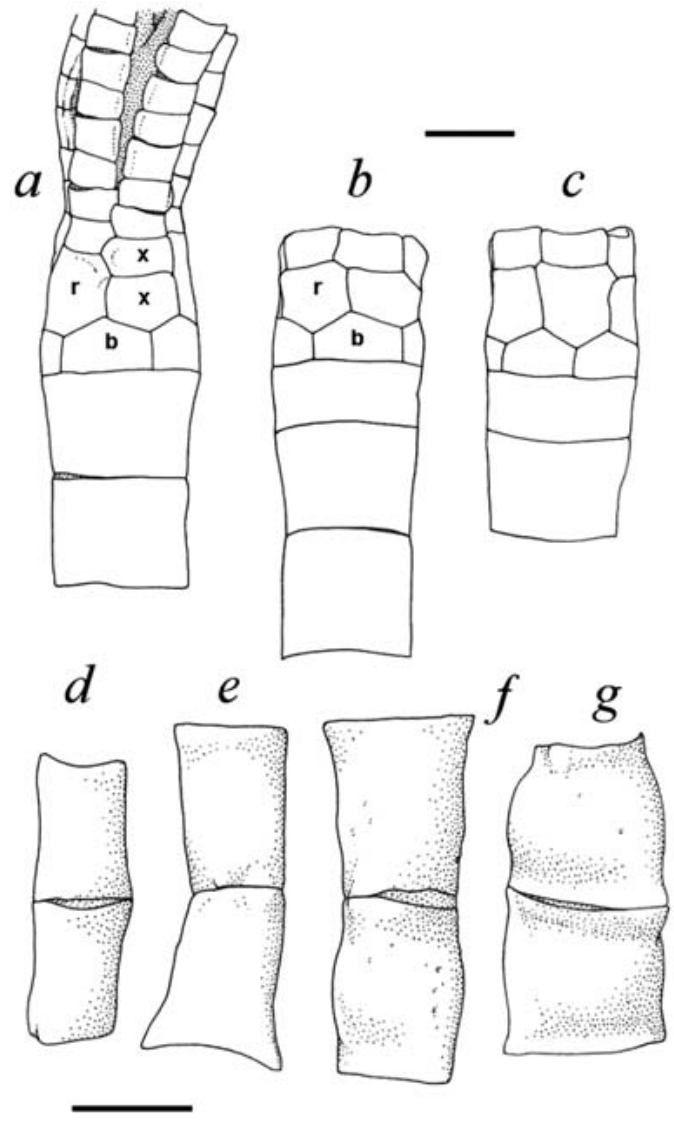

Figure 7. Porphyrocrinus verrucosus Gislén. $a, d-g$. СRECH 157. a, Proximal two columnals, calyx, including transversely divided radial ossicle (x), and bases of four rays (regenerating). $d$, Columnals 16-17. e, Columnals 3334. $f$, Columnals 48-49. $g$, Columnals 61-62. $b-c$. CRECH 144 , two views of proximal columnals, calyx, and first brachial ossicle. r, radial ossicle; b, basal ossicle. Scale bars: upper $(a-c): 2 \mathrm{~mm}$; lower $(d-g): 5 \mathrm{~mm}$.

one radial ossicle divided transversely. Distal brachials with muscular articulations alternating with synostoses but with the latter not immovably fused. First pinnule arising from right side of br8 (2 rays) and left side of br10 (3 rays). Distal pinnules similar to those of preceding specimen but up to $11 \mathrm{~mm}$ long with 26 segments.

Remaining stalk $37.8 \mathrm{~cm}$ long, of 64 columnals. No proxistele of thin apical colum- nals; topmost columnal slightly narrower distally, LW 0.8. Following several columnals cylindrical, increasing gradually in diameter from the 10th as long axes of synarthrial articulations begin to project; maximum distal stalk diameter $6.8 \mathrm{~mm}$. Columnals beyond the first increasing in length; 3rd with $\mathrm{LW}$ 1.0 ; columnals in middle of stalk more elongated than in preceding specimen, $\mathrm{LW}$ up to 1.6; distal columnals swollen and shorter, $\mathrm{LW}$ 1.0-0.9. No ankylosed articulations.

CRECH 144 (Figures $5 b, 7 b-c$ ): Crown of 6 regenerating rays, $3.2 \mathrm{~mm}$ across base; $\mathrm{R}=58 \mathrm{~mm}$; all arms detached beyond br1. Calyx wider than tall, LW 0.7. Radial circlet (3.0 $\mathrm{mm}$ across) slightly narrower than basal circlet $(3.3 \mathrm{~mm})$. Five pentagonal basals wider than long, LW 0.5-0.6; 6 radials irregularly pentagonal or hexagonal, LW 0.7-1.0. Br1 LW 0.6. Distal articular facet of br1 shallowly concave (a slight symmorphy) with wide, flat rim; a round knob or mound in facet center extending aborally as a small (fulcral?) ridge that does not reach aboral facet margin. First pinnule arising from left side of br10 (3 rays), br12 (1 ray), or br11 (2 rays; but with synostoses at br $3+4,5+6+7$, $8+9,10+11$ and br4+5, 6+7, 8+9, 10+11).

Stalk $38.2 \mathrm{~cm}$ long, of 70 columnals plus attachment disk; broken in two pieces near base. No proxistele of thin apical columnals; topmost columnal slightly narrower distally, $3.2 \mathrm{~mm}$ across, LW 0.4, joined to second columnal by synostosis; second columnal cylindric, $2.8 \mathrm{~mm}$ across, LW 0.9; following columnals articulated by synarthry except for an ankylosis at $63+64$ and another between the distalmost columnal and attachment disk, and increasing gradually in diameter from distal end of 10th. Middle and distal columnals similar to those of CRECH 157; middle columnals with LW chiefly 1.8; distal several columnals shorter, LW 0.7-1.1; maximum diameter across distalmost columnal $6.6 \mathrm{~mm}$.

The genus Porpbyrocrinus currently contains four species (Roux et al. 2002) distinguished chiefly by size, proportions of calyx ossicles, number of thin proximal columnals, and arrangement of secondary synostoses in the distal stalk. Porphyrocrinus thalassae Roux, 1977 (Northeast Atlantic, 1,700-2,750 m), is 
characterized by arms branched at br8-10 and a well-developed proxistele of $>15$ thin columnals (Roux 1977, 1985, A. M. Clark 1982). The other species have five unbranched arms without pinnules before br8. Porphyrocrinus incrassatus (Gislén, 1933) (Northeast and South Atlantic, 1,300-2,780 $\mathrm{m})$ is the smallest, with a proxistele of $\sim 10$ columnals, tall middle columnals (mesistele) united by synarthries with circular facets, and distal columnals wider than tall (dististele) with strongly elliptical synarthries (Gislén 1933, Roux 1977, Roux et al. 2002). The two Indo-West-Pacific species, $P$. polyartbra A. M. Clark, 1973 (Southwest Indian Ocean, 400 m) and $P$. verrucosus Gislén, 1925 (Kepaualan $\mathrm{Kai}$, Indonesia, $345 \mathrm{~m}$ ), are closely similar. A. M. Clark (1973) distinguished P. polyarthra from $P$. verrucosus by the former's larger size, greater number of thin proximal columnals, multiple distal stalk synostoses, and lack of calcareous granulations on the distal columnals. However, she noted that the number of thin proximal columnals varied widely (8 in $P$. verrucosus; 11-17 in $P$. polyarthra), varied with growth in related taxa, and that the single specimen of $P$. verrucosus lacked the distal end of the stalk where the multiple synostoses of $P$. polyarthra occurred.

A. M. Clark (1973) called these rigid stalk articulations synostoses but described and figured their external appearance as the interrupted line of a syzygy. Roux et al. (2002:805) noted that deposition of such marginal secondary stereom reflects "the transformation of a flexible juvenile articulation into an adult rigid articulation." In the Palauan material, the synarthries may be secondarily ankylosed either by a continuous crescent of dense calcite-appearing externally as a synostosis-or by an irregular series of patches-appearing externally as a syzygy-even on the same facet (Figure 6).

Although two of the Palauan specimens have six rays rather than the standard five, all three specimens clearly belong to a single taxon, and their variations suggest that the two nominal Indo-West-Pacific species may not warrant separate status. A. H. Clark (1917) described the only other known example of a six-rayed stalked crinoid crown-in the bathycrinid Monachocrinus sexradiatus, known from a single Northeast Atlantic specimen.

The absence of thin apical columnals in the two specimens with regenerating crowns-reflecting a redirection of metabolic resources from stalk growth to crown regeneration-illustrates that the number of these ossicles may vary with the physiological state of the individual. These specimens also have elongate middle columnals, similar to those of $P$. polyarthra and $P$. verrucosus but differing from the shorter barrel-like columnals of the specimen with the intact crown.

Variations in the location of the first pinnule and in the frequency and placement of rigid stalk articulations in the Palauan specimens span the ranges of these features in $P$. polyartbra and $P$. verrucosus and eliminate them as diagnostic features. The three known specimens of $P$. polyarthra and $P$. verrucosus with crowns are also substantially smaller than the Palauan specimens (apical stalk diameters 1.1-1.5 mm versus $2.6-3.5 \mathrm{~mm}$ ), which accounts for differences in proportions of calyx ossicles-smaller $P$. polyarthra in particular having more elongated ossicles as is typical of younger growth stages of many living crinoids. The larger size-and assumed greater age-of the Palauan specimens may also account for the pitting of their distal columnals (also noted in P. verrucosus), the frequency of ankylosed synarthries, and apparent fragmentation of some of the thin apical columnals in CRECH 147.

The variations described here effectively eliminate all characteristics that might distinguish $P$. verrucosus, $P$. polyarthra, and the Palauan specimens as distinct taxa, with the exception of the calcareous granulations characteristic of the distal stalk in $P$. verrucosus. Because this species is known only from a single specimen, the importance of these granulations cannot be evaluated. As a result, and because of their close geographic and bathymetric proximity, the Palauan specimens are referred to P. verrucosus. Porphyrocrinus polyarthra is also considered a junior synonym of $P$. verrucosus. However, detailed descriptions of the articular facets of these crinoids, especially the proximal cryptosym- 
plexies and distal rigid articulations, may reveal additional distinguishing characters.

Alternative hypotheses that may explain why two of three specimens of $P$. verrucosus have regenerating crowns include nonlethal predation (though no candidate predators have been observed), turbidity flows triggered by tropical storms, and slumping events generated by shallow reef bioerosion. The numerous apparent slump blocks and dammed sediment suggest an unstable environment, though the frequency of such events relative to crinoid longevity and recruitment is unknown.

\section{DISCUSSION}

The combination of taxonomic revisions since the original survey and the new finds reported here maintain about the same richness of shallow-water crinoids in Palauan waters: 21 species (Meyer and Macurda 1980) versus 22 (2002 survey). Further taxonomic analyses may revise this figure (e.g., if the shallow and deep forms of Oxycomanthus bennetti and Lamprometra palmata form brachypecha prove to be distinct species). Other additions to the Palauan fauna are also possible: Comanthus wablbergii, Comatella stelligera, and (anecdotally) Colobometra perspinosa, and specimens tentatively referred to Oxycomanthus mirus and Phanogenia distincta are known from Guam, the Northern Mariana Islands, or Chuuk, Federated States of Micronesia, as well as from the East Indian Archipelago (Messing 1998a, Kirkendale and Messing 2003). Such additions would smooth the west-to-east decline in shallow-water crinoid richness across Micronesia, from close to 30 at Palau through 21 at Chuuk to 14 in the Marshall Islands (Kirkendale and Messing 2003).

Station-by-station results of the 2002 scuba survey and those of Meyer and Macurda (1980) are not strictly comparable because of the taxonomic revisions and differences in effort between the two. However, the four sites examined with similar effort in both surveys returned similar species richness levels (Table 2). One difference between the two surveys is the apparent marked decrease
TABLE 2

Species Richness at Sites Surveyed Both by Meyer and Macurda (1980) and in 2002 Relative to Collecting Effort (Numbers of Dives). Similar Effort Returned Similar Richness. Sites Are Listed in Order of Increasing Effort in the Earlier Survey. The Lower Three Rows Indicate Sites Surveyed Much More Thoroughly by Meyer and Macurda (1980)

\begin{tabular}{ccrcc}
\hline \hline \multicolumn{2}{c}{$\begin{array}{c}\text { Meyer and Macurda } \\
(1980)\end{array}$} & & \multicolumn{2}{c}{2002 survey } \\
\cline { 1 - 2 } \cline { 5 - 5 } Site no. & No. species & & Site no. & No. species \\
\hline $9(1)$ & 5 & & $2(1)$ & 3 \\
$13(2)$ & 3 & & $13(1)$ & 1 \\
$20(2)$ & 10 & & $8,12(2)$ & 13 \\
$14(5)$ & 13 & & $15(1)$ & 12 \\
$3(9)$ & 11 & & $14(1)$ & 5 \\
$6(10)$ & 11 & & $3(1)$ & 3 \\
$12(16)$ & 10 & & $4(1)$ & 4 \\
\hline
\end{tabular}

in Pontiometra andersoni in 2002. Meyer and Macurda (1980:90) found this large, conspicuous species at 15 of 22 sites, "in greatest abundance on the inner reefs ... particularly along the passes." The 2002 survey visited three of these (and a fourth nearby with similar habitat) and found no P. andersoni. A single specimen was found at site 11 outside the area of the earlier survey.

The 2002 scuba survey and the submersible collections strengthen the link between the crinoid fauna of Micronesia and the East Indies. All previously described species have also been recorded from Indonesia or the Philippines, as have alternative taxa for those species identified tentatively (i.e., Palaeocomatella biwia, Glyptometra crassa, and G. inaequalis). Although the behavior and habitat of Capillaster cf. multiradiatus in Palau have not been reported from the East Indies, specimens from the latter area exhibit so much variation that, even if the Palauan form represents a species distinct from those at Madang and Palawan, it is unlikely to be an endemic. It may alternatively reflect an adaptive epigenetic response to local environmental conditions. The species of Cosmiometra most closely similar to $C$. belsuchel are also known from the Philippines and Indonesia.

Although more work is needed, it appears 
likely that a substantial number of common East Indian shallow-water taxa do not reach Palau despite a series of potential island stepping-stones [e.g., the family Himerometridae, Capillaster sentosus, Clarkcomanthus albinotus, Comanthus gisleni, Comanthus mirabilis, Phanogenia multibrachiata (Comasteridae), Basilometra boscbmai, and Petasometra clarae (Colobometridae)]. It would be interesting to examine the pattern of distribution of crinoids from Halmahera in northeastern Indonesia through Hatohobei and Helen Reef, Merir, Pulo Anna, and the Sonsorol Islands to Palau, a distance of about $650 \mathrm{~km}$. No information on larval ecology or longevity that might explain this distributional gradient exists for any of the species treated here.

\section{ACKNOWLEDGMENTS}

I gratefully thank Patrick and Lori Colin, Directors of the Coral Reef Research Foundation (CRRF), Koror, Palau, for sponsoring the 2002 survey, for their hospitality and friendship, for making the specimens collected by submersible available for study, for their prompt willingness to send data and ship specimens to me at the drop of a hat, and for researching the new species name. Submersible collections were made by CRRF through a contract with the U.S. National Cancer Institute (No. N02-CM-77249). Thanks are also due to Nick Pilcher and Emilio Basilius for diving with me and to Michel Roux (Université de Reims) for helpful comments about Porphyrocrinus.

\section{Literature Cited}

Améziane, N. 1997. Echinodermata Crinoidea: Les Pentacrines récoltées lors de la campagne KARUBAR en Indonésie. In A. Crosnier and P. Bouchet, eds. Résultats des Campagnes MUSORSTOM 16. Mem. Mus. Natl. Hist. Nat. 172:627-667.

Améziane-Cominardi, N. 1991. Distribution bathymétrique des pentacrines du Pacifique Occidental. Essai de modélisation et d'application au faunes du Lias (Problèmes de tectono-eustatisme au cours du rifting téthysien). Doc. Lab. Geol. Fac. Sci. Lyon (116): 1-253, 5 pls.

Bradbury, R. H., R. E. Reichelt, D. L. Meyer, and R. A. Birtles. 1987. Patterns in the distribution of the crinoid community at Davies Reef on the central Great Barrier Reef. Coral Reefs 5:189-196.

Chen, J.-C., K.-H. Chang, and C.-P. Chen. 1988. Shallow water crinoids of Kenting National Park, Taiwan. Bull. Inst. Zool. Acad. Sinica (Taipei) 27:73-90.

Clark, A. H. 1912. Six new East Indian crinoids belonging to the family Charitometridae. Proc. Biol. Soc. Wash. 25:77-84. 1917. A revision of the recent genera of the family Bourgueticrinidae with the description of a new genus. J. Acad. Sci. Wash. 7:388-392.

- 1941. A monograph of the existing crinoids. 1(4a). U.S. Natl. Mus. Bull. 82:1603,61 pls.

- 1947. A monograph of the existing crinoids. 1(4b). U.S. Natl. Mus. Bull. 82:1-473, 43 pls.

. 1950. A monograph of the existing crinoids. 1(4c). U.S. Natl. Mus. Bull. 82:1383,32 pls.

Clark, A. M. 1972. Some crinoids from the Indian Ocean. Bull. Br. Mus. (Nat. Hist.) Zool. 24 (2): 75-156.

- 1973. Some taxa of recent stalked Crinoidea. Bull. Br. Mus. (Nat. Hist.) Zool. 25 (7): 267-288.

. 1982. Inter-relationships of recent stalked non-isocrinid Crinoidea. Aust. Mus. Syd. Mem. 16:121-128.

Clark, A. M., and P. S. Davies. 1965. Echinoderms of the Maldive Islands. Ann. Mag. Nat. Hist. 8 (94): 597-612, 1 pl.

Clark, A. M., and F. W. E. Rowe. 1971. Monograph of shallow-water Indo-West Pacific Echinoderms. British Museum (Natural History), London. $\mathrm{x}+238$ p. +30 pls.

Gislén, T. 1925. Two new stalked crinoids from the Kei Islands. Vidensk. Medd. Dan. Naturhist. Foren. 79:85-95.

1933. A collection of crinoids from St. Helena. Vidensk. Medd. Dan. Naturhist. Foren. 93:476-485, 1 pl. 
1938. A revision of the recent Bathycrinidae, with a study of their phylogeny and geographical distribution. Acta Univ. Lund. 34 (10): 1-30.

1940. A collection of crinoids from the South Sea Islands. K. Sven. Vetenskapsakad. Handl. (3) 18 (10): 1-16, 3 pls.

Hamner, W. M. 1982. Strange world of Palau's salt lakes. Natl. Geogr. 161 (2): 264-282.

Hoggett, A. K., and F. W. E. Rowe. 1986. A reappraisal of the family Comasteridae A. H. Clark, 1908 (Echinodermata: Crinoidea), with the description of a new subfamily and a new genus. Zool. J. Linn. Soc. 88:103-142.

Kirkendale, L., and C. G. Messing. 2003. An annotated checklist and key to the Crinoidea of Guam and the Commonwealth of the Northern Mariana Islands. Micronesica 35-36:523-546.

Kogo, I. 1998. Crinoids from Japan and its adjacent waters. Spec. Publ. Osaka Mus. Nat. Hist. 30:1-148.

Kogo, I., and T. Fujita. 2005. Geographical distribution of crinoids (Echinodermata) in southwestern Japan. Pages 297-335 in K. Hasegawa, G. Shinohara, and M. Takeda, eds. Deep-sea fauna and pollutants in Nansei Islands. Natl. Sci. Mus. Monogr. 29, Tokyo.

Messing, C. G. 1994. Comatulid crinoids (Echinodermata) of Madang, Papua New Guinea, and environs: Diversity and ecology. Pages 237-243 in B. David, A. Guille, J.-P. Feral, and M. Roux, eds. Echinoderms through time. Balkema, Rotterdam. . 1995. Alloeocomatella, a new genus of reef-dwelling feather star from the tropical Indo-West Pacific (Echinodermata: Crinoidea: Comasteridae). Proc. Biol. Soc. Wash. 108 (3): 436-450.

. 1997. Living comatulids. Pages 3-30 in J. Waters and C. Maples, eds. Geobiology of Echinoderms. Paleontol. Soc. Pap. 3.

1998a. An initial re-assessment of the distribution and diversity of the East Indian shallow-water crinoid fauna. Pages 187-192 in R. Mooi and M. Telford, eds.
Echinoderms: San Francisco. Balkema, Rotterdam.

1998b. A revision of the Recent Indo-West Pacific comatulid genus Comaster Agassiz. Part 1: The type species of Comaster and Phanogenia Lovén (Echinodermata: Crinoidea: Comasteridae). Invertebr. Taxon. 12:191-209. 2001. A key to the genera of Comasteridae (Echinodermata: Crinoidea) with the description of a new genus. Bull. Biol. Soc. Wash. 10:277-300.

Messing, C. G., N. Améziane, and M. Eleaume. 2000. Comatulid crinoids of the KARUBAR Expedition to Indonesia: The families Comasteridae, Asterometridae, Calometridae and Thalassometridae (Echinodermata: Crinoidea). In A. Crosnier and P. Bouchet, eds. Résultats des Campagnes MUSORSTOM 21. Mem. Mus. Natl. Hist. Nat. 184:627-702.

Meyer, D. L. 1986. Les Crinoides. Pages 199-225 in A. Guille, P. Laboute, and J. L. Menou, eds. Guide des etoiles de mer, oursins et autres echinodermes du lagon de Nouvelle-Caledonie. Editions de l'ORSTOM, Collection Faune Tropicale no. XXV, Paris.

Meyer, D. L., and D. B. Macurda Jr. 1980. Ecology and distribution of the shallowwater crinoids (Echinodermata) of the Palau Islands and Guam (western Pacific). Micronesica 16:59-99.

Rankin, D. L. 2000. A taxonomic reevaluation of the comatulid genus Stephanometra (Echinodermata, Crinoidea, Mariametridae). M.S. thesis. Nova Southeastern University, Fort Lauderdale, Florida.

Roux, M. 1977. Les Bourgueticrinina (Crinoidea) recueillis par la Thalassa dans le Golfe de Gascogne: Anatomie comparée des pédoncules et systématique. Bull. Mus. Natl. Hist. Nat. (3) 426 (Zool. 296): 26-82. - 1985. Les crinoïdes pédonculés (Echinodermes) de l'Atlantique du NordEst: Inventaire, écologie et biogéographie. Pages 479-489 in L. Laubier and C. Monniot, eds. Peuplements profonds du Golfe de Gascogne, IFREMER, Paris. 
Roux, M., C. G. Messing, and N. Améziane. 2002. Artificial keys to the genera of living stalked crinoids (Echinodermata). Bull. Mar. Sci. 70 (3): 799-830.

Rowe, F. W. E., and J. Gates. 1995. Echinodermata. Pages xiii +510 in A. Wells, ed. Zoological catalogue of Australia. 33, CSIRO Australia, Melbourne.

Rowe, F. W. E., A. K. Hoggett, R. A. Birtles, and L. L. Vail. 1986. Revision of some comasterid genera from Australia (Echinodermata: Crinoidea), with descriptions of two new genera and nine new species. Zool. J. Linn. Soc. 86:197-277.

Stephens, T. F. 1989. Species composition and distribution of the comatulid crinoids of Heron Island and Wistari Reefs. M.S. thesis, University of Queensland, Brisbane, Australia.

Vail, L. 1987. Diel patterns of emergence of crinoids (Echinodermata) from within a reef at Lizard Island, Great Barrier Reef, Australia. Mar. Biol. (Berl.) 93:551-560.

Zmarzly, D. L. 1984. Distribution and ecology of shallow-water crinoids at Enewetak Atoll, Marshall Islands, with an annotated checklist of their symbionts. Pac. Sci. 38:105-122.

-1985. The shallow-water crinoid fauna of Kwajalein Atoll, Marshall Islands: Ecological observations, interatoll comparisons, and zoogeographic affinities. Pac. Sci. 39:340-358. 
